\title{
TRANSFORMING SUSTAINABILITY IN THE TIME OF PANDEMIC
}

\section{DAN PODJED AND LANA PETERNEL}

The central message of this journal issue is that the social science and humanities in collaboration with other fields of science should put more attention to redefining sustainability as a concept which has been used and abused from its inception and has meanwhile lost a part of significance. The covid-19 pandemic presents an opportunity to carry out the transformation, to re-think the basic concepts of sustainability and to adapt them to the new circumstances. Keywords: sustainability, transformation, covid-19pandemic, tragedy of the commons, environment
Osrednje sporočilo te številke revije je, da bi morala družboslovje in humanistika $v$ sodelovanju z drugimi znanstvenimi področji nameniti več pozornosti ponovnemu definiranju trajnostnega razvoja kot koncepta, ki je bil od svojega nastanka pogosto uporabljen in zlorabljen ter je medtem izgubil bistven del svojega pomena. Pandemija covid-19 pomeni priložnost za preobrazbo trajnostnega razvoja, prevrednotenje temeljnih pojmov in njihovo prilagajanje novim okolišcinam.

Ključne besede: trajnostni razvoj, transformacija, pandemija covid-19, tragedija skupnega, okolje

During the covid-19 pandemic which was announced by the World Health Organization in early 2020, the public discourse has shifted in unexpected directions. It has increasingly started to involve ideas of entrepreneurs from the green sector, emphasizing them as the people who bring innovative values and desperately needed changes for the post-pandemic future. All of a sudden, the main focus was on small-scale farmers and the family organic farms that produce locally grown healthy foods and contribute to the sustainable way of living and doing business, preserving the environment for future generations.

For example, a female entrepreneur who defined sustainability as her life choice and business philosophy more than thirty years ago, appeared in a Croatian TV show and presented the transformation of her ideas which were driven by sustainability. In the interview she explained the drivers of change: "We as green sustainable entrepreneurs have relied too much on growth in the last few decades. We have invested too much. We were too eager to be present. We, the pioneers in green business, have to transform our basic concepts." This pioneer of sustainable business has built her life and work, as well as her philosophy of sustainability, by resisting the dominant economic values. In addition, she admitted that her way of doing green business was not at all appropriate for what she was about to face during and after the pandemic.

In other words, much earlier than we could have imagined, the topic in focus of this issue of Traditiones, initiated in September 2019 at the Transforming Sustainability conference in Ljubljana, came to the spotlight and was given the opportunity to be re-examined and rethought. The new circumstances have directed us towards different reflection on the transformation of sustainability than we had initially envisioned. Together with contributors 
to this thematic issue, we examined the forms of resisting or adopting new values, norms and habits, yet still within the existing framework of intensive mobility, communication and consumption. At the end, we were forced to prepare this thematic issue in isolation while seeking innovative methods to be applied in our field of work.

Of course, this is not the first such event for our disciplines. Until now, anthropology and ethnology have "weathered the storm" of many crises. However, hardly any of us, the authors of this issue, imagined that the "bread and butter" of ethnographic field techniques in the form of direct interviews and participant observation would come into question and no one imagined that our work would be shifted to the digital form for a longer period. There have been suggestions to "transpose" our topics and work into new systems and new forms of examining reality. Indeed, that is always a desirable option, however, we did not really think of it as the only one to be left with. Therefore, we have to raise once more the question about the meaning of sustainability. In addition to answering the question from the contemporary view, we want to emphasise the possible scenarios for the future - including the utopian and dystopian versions, similar to the one presented decades ago.

Namely, in 1968 ecologist Garrett Hardin published in Science his ground-breaking article The Tragedy of the Commons, in which he explained how and why individuals egoistically exploit shared resources, despite their understanding that depleting common resources is contrary to the group's long-term best interests. "Freedom in a commons brings ruin to all," concluded Hardin the text in a pessimistic mood (Hardin 1968). Hardin's ideas were later refuted by various scholars, including Elinor Ostrom (1990) who presented the "grassroots" solutions that prevent over-exploitation of the commons by mutual control of peers. However, Hardin's central idea has been constantly re-appearing and it has become obvious there was no solution for his mind experiment on the global scale, where the humanity shared the same scarce resources, e.g. oil, water, and air. The "ruin for all" if we don't change our habits and practices and especially type of production has become a global mantra of environmental movements and "green politicians". In 2019, Greta Thunberg, the young environmentalist and frontwoman of the informal movement School Strike for Climate which organised several massive demonstrations, became Person of the Year of the Time magazine and was nominated for the Nobel Peace Prize.

In 2020, something extraordinary occurred, which would be named the "Black Swan" according to Nassim Nicholas Taleb (2007). The covid-19 pandemic has become the central international issue which has influenced lifestyle of almost every person on the planet. International borders were closed and people were confined to their homes, which reduced transport and changed production and consumption patterns. The ominous exponential curve which shows the growth of planetary emissions of greenhouse gases has finally turned downwards. According to estimates published in the journal Nature, the amount of carbon dioxide humans are responsible for generating worldwide each day fell by 17 percent in April 2020 compared to the daily average for 2019. That gets the world to about the same amount of $\mathrm{CO}_{2}$ it was pumped out in 2006 (Le Quéré 2020). 
How can we bring together different lifestyle changes - the ones supported by Greta Thunberg and the others which happened accidentally due to the pandemic? The first thing that should be carried out is to re-evaluate the term "sustainability" which has become somewhat outdated and over-exploited in the past. This issue of Traditiones therefore examines the meaning and relevance of sustainability in relation to contemporary socio-cultural, economic and environmental issues. The questions that contributors aim to untangle are: How do people experience and value sustainability as a global trend, personal attitude and survival strategy? How does the lack of a common perspective on sustainability prevent future social and cultural transformations? Can we define sustainability as a dominant concept for universal social development or do we need to transform its meaning and adapt it to new social, cultural, and economic dilemmas? Can sustainable lifestyle and practices, such as recycling, organic food production and responsible energy use, actually improve our health and subjective well-being?

By answering these questions, two more recent developmental models, green economy and degrowth, will be discussed theoretically and analytically. As described by Kallis et al. (2018: 292), economic growth is "an integrated cultural, political, ecological and economic process manifested as an increase in the total market value of all goods and services (GDP)", and degrowth, as its opposite, "a process of political and social transformation that reduces a society's throughput while improving the quality of life". The issue of the journal attempts to evaluate these and other similar terms, such as "circular economy", "steady-state economy", "post-growth" and "buen vivir," present them from the viewpoint of the social sciences and humanities and identify new concepts and meanings that could be compatible with contemporary research approaches and useful for academics and practitioners. Special emphasis at the conference is placed on mobility, waste management and agriculture, as well as other human activities and practices that have a significant impact on the planet and wellbeing of current and future communities.

This issue begins with a contribution of Nikola Petrović, Lana Peternel and Branko Ančić (2020) who explored how particular layers of the Western Zeitgeist and the Croatian social and economic context influenced the emergence and development of green entrepreneurship. They argue whether sustainable economy could be helpful in understanding undiscovered potential in the global social transition and examine the label of rejectionist ethic to encompass different modes of refusing modern economic patterns and the usual life trajectories. According to posed questions and insights in the study, rejection as a concept is a preliminary phase that calls for further attention and ethnographic inquiry narrowing the approach on longitudinal consequences of transformation of everyday lives. By following transformation as a process, Tatiana Bajuk Senčar (2020) discusses the issue of agency in an age defined by common challenges that manifest themselves both locally and globally. In particular, she argues for a dispersed, non-linear understanding of individual agency as it relates to the global crisis of plastic waste as a way of examining and assessing strategies of change. By aiming to answer the question "Who Wants What And Why?" 
Jelena Puđak and Nataša Bokan (2020) explore motivations of green entrepreneurs and try to understand values considering alternative economic models. Their findings suggest the green entrepreneurs differ in their motivations for the green venture they undertake. It appears the values and motives of "farmers" are much closer to the degrowth idea, while the "engineers" are more in line with the green economy outlook. These findings point to the importance of socio-contextual aspects that underline the appearance of different green entrepreneurial types. The next article, prepared by Daša Ličen and Dan Podjed (2020), investigates two environmental movements that arose from grassroots initiatives. The first is Ecologists without Borders, the leading Slovenian NGO promoting waste reduction, and the second Critical Mass, an international cyclists' movement that seeks more public space for urban cyclists in different cities, including Budapest and Belgrade. The authors use these cases to investigate the social transition that such movements support and shed light on how they arise, function, and change over time. Furthermore, the issue brings an article of Maja Pivec and Jane Lu Hsu (2020) which reports on the applied research into finding ways to increase sustainable behaviour with the application of game mechanics and playful solutions. One of the main questions of their text was what would motivate each of us to adopt a more sustainable behaviour and sustainable consumption.

To prepare the next two articles of this issue, the authors had to start "digging through trash." Dan Podjed and Katarina Polajnar Horvat (2020) presented the findings of a study on household food waste. The authors combined different methods to obtain a broader picture and explain how, when, and why people "transform" food into waste. A different and intriguing view on the waste is presented by Saša Babič. In her study (2020), she examined the concept and metaphorical meaning of waste and dirt in short folklore forms and internet memes. As it is explained in her contribution, waste and dirt are traditionally conceptually linked to metaphors of unwanted, used, or lower-quality. New forms, on the other hand, emphasize environmental pollution directly, using concepts of waste and pollution combined in words and images intended to persuade the viewer or recipient to change their behavior into environmentally responsible behavior.

The last article in this issue presents results of a qualitative study on degrowth. Marija Brajdić Vuković, Branko Ančić and Mladen Domazet (2020) put attention on attitudes, values and ideologies as potentials in influencing cultural change toward more environmentally and socially sustainable socio-political system. The main framework of the discussion is the degrowth paradigm and the results of analyses are based on the two modules of the International Social Survey Program. The main indicator of the (social) degrowth potentiality is the "degrowth scale," consisting of dimensions related to the end of economic growth and the need for social change. Those dimensions are (statistically) contextualised within respondents' socio-demographic characteristics, and their other values and attitudes, and discussed within the degrowth paradigm.

The central message of this issue is that the social science and humanities in collaboration with other fields of science should put more attention to redefining sustainability 
as a concept which has been used and abused from its inception and has meanwhile lost a part of significance. After the covid-19 pandemic, which made a historical cut in our daily habits and consumption patterns, the time has come to re-think such basic concepts and when necessary - transform and adapt them to the new time, circumstances and lifestyles.

\section{REFERENCES}

Babič, Saša. 2020. Waste and Dirt in Short Folklore Forms. Traditiones 49 (1): 125-139. DOI: https://doi. org/10.3986/Traditio2020490107

Bajuk Senčar, Tatiana. 2020. Reframing Agency in the Face of Global Challenges: The Problem of Plastic Waste. Traditiones 49 (1): 37-53. DOI: https://doi.org/10.3986/Traditio2020490102

Brajdić Vuković, Marija, Branko Ančić, and Mladen Domazet. 2020. Values Underpinning Degrowth Transformation of Socio-Political System. Traditiones 49 (1): 141-158. DOI: https://doi.org/10.3986/ Traditio2020490108

Hardin, Garrett. 1968. The Tragedy of the Commons. Science 162 (3859): 1243-1248.

Kallis, Giorgos. 2018. Degrowth. Newcastle upon Tyne: Agenda Publishing.

Le Quéré, Corinne et al. 2020. Temporary Reduction in Daily Global CO2 Emissions during the COVID19 Forced Confinement. Nature Climate Change. https:/doi.org/10.1038/s41558-020-0797-x

Ličen, Daša, and Dan Podjed. 2020. Making a Change from Below: A Comparative Study of Popular Movements for Reducing Waste and Promoting Cycling. Traditiones 49 (1): 75-91. DOI: https:// doi.org/10.3986/Traditio2020490104

Ostrom, Elinor. 1990. Governing the Commons: The Evolution of Institutions for Collective Action. Cambridge and New York: Cambridge University Press.

Petrović, Nikola, Lana Peternel, and Branko Ančić. 2020. The Rejectionist Ethic and the Spirit of the Green Economy: The Western Zeitgeist, the Croatian Context, and Green Entrepreneurship. Traditiones 49 (1): 13-36. DOI: https://doi.org/10.3986/Traditio2020490101

Pivec, Maja, and Jane Lu Hsu. 2020. Motivation for Change: Gamification as a Tool for Supporting Sustainable Behaviour. Traditiones 49 (1): 93-108. DOI: https://doi.org/10.3986/Traditio2020490105

Podjed, Dan, and Katarina Polajnar Horvat. 2020. The Invisible Life of Food Waste: The Case of Ljubljana Households. Traditiones 49 (1): 109-124. DOI: https://doi.org/10.3986/Traditio2020490106

Puđak, Jelena, and Nataša Bokan. 2020. Who Wants What and Why? 'Farmers' and 'Engineers' as Green Entrepreneurs. Traditiones 49 (1): 55-74. DOI: https://doi.org/10.3986/Traditio2020490103

Taleb, Nassim Nicholas. 2007. The Black Swan: The Impact of the Highly Improbable. New York: Random House. 
Assist. Prof. Dr. Dan Podjed, Research Fellow, ZRC SAZU, Institute of Slovenian Ethnology, Novi trg 2, 1000 Ljubljana, Slovenia

and

University of Ljubljana, Faculty of Arts, Department of Ethnology and Cultural Anthropology, Aškerčeva 2, 1000 Ljubljana, Slovenia,dan.podjed@zrc-sazu.si

Dr. Lana Peternel, Research Associate, Centre for Research in Social Inequalities and Sustainability (CIDNO), Institute for Social Research in Zagreb, Frankopanska 22, 10000 Zagreb, Croatia, lanapeternel@idi.hr 